\title{
Spectral and Thermal Properties of Some Uranyl Complexes of Some Schiff-Bases Derived from Glycylglycine
}

\author{
Sh. A. Sallam ${ }^{*}$ and M. I. Ayad ${ }^{\dagger}$

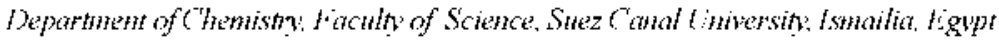

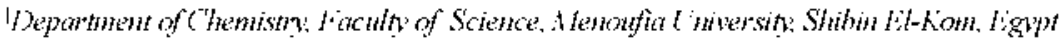 \\ (2(k)3.2. 7 전수)
}

\section{Spectral and Thermal Properties of Some Uranyl Complexes of Some Schiff-Bases Derived from Glycylglycine}

\author{
Sh. A. Sallam* and M. I. Ayad ${ }^{\dagger}$

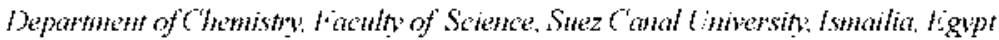

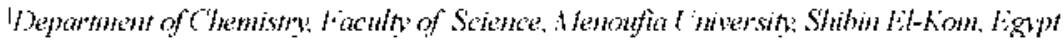 \\ (Received l'ebruary 7.2013)
}

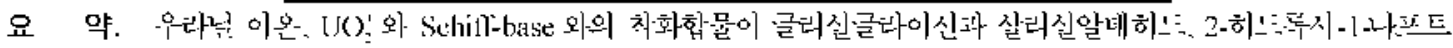

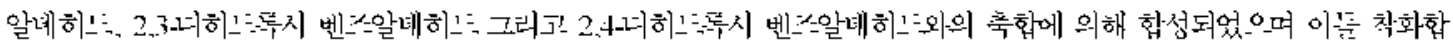
꿀의 특성은 원소분석. 친도도 측성. 사기화율 측싱. UV. IR. NMR 스펙트라와 DTA. TG. DSC 견과를 이용하여 조 사하였다. 구즈와 열 분해 메카네즘이 제한되었다.

주제어: 엄라닉이온, 착화합물, 구쏘. 열분해
\end{abstract}

\begin{abstract}
Complexes of urany ion $\mathrm{CO}_{2}{ }^{2}$ with Sehift-bases obtained by condensing glycylglycine with salieylaldehỵde: 2-hydroxy-1-naphthaldehr de. 2.3-dihy droxy benzaldehyde. and 2.4-dihydroxybenzaldehy de have been synthesized and characterized through clemental analysis. conductivity measurements. magnetic susceptibility determinations. u.y. i.r. and ${ }^{~} \mathrm{H}$ mmr speetra as well as d.t.a. t.g. and d.s.e. techniques. Struetures and mechanisms of thermal decomposition are proposed.
\end{abstract}

Keywords: Glycylglycine Schitt-Bases. Uranyl Complexes. Strueture and Thermal Properties. Decomposition Mcchanism

\section{INTRODUCTION}

Schiff-basce are important class of ligands in coordination ehemistry and have phamacological as well as physiological activitics. ${ }^{1-3}$ Metal complexes of Sehiff-hases derived from amino-acids play an important roles as the hasic compounds for modeling more complicated l'Ll'-amino-acid schitt-bases ${ }^{\text {L. }}$ lhey ate key intermediates in a variety of metabolic reactions insolving amino-acids such as decarbosylation, transamination, racemization and $C-C$ bond cleavage, which are catalyzed by enzymes.10 $\Lambda$ number of studies have been undertaken on these and related swstems in both solution and wolid state with the aim of elucidating the reaction mechatnisms. ${ }^{11-20}$

Interaction of Schifl-báses derived from wálicyláldehyde and amino-acids with $\mathrm{Mn}$ (II) acetate and $\mathrm{Cr}(\mathrm{II})$ chloride in $\mathrm{FtOH} / \mathrm{H}_{2} \mathrm{O}$ medium gave complexes with composition $\mathrm{Mn}(\mathrm{sal}-\mathrm{aa}), 2 \mathrm{I}_{2} \mathrm{O}$ and $\mathrm{Cr}$ (sal-aa) $\mathrm{Cl}_{2} 2 \mathrm{I}_{2} \mathrm{O}$ respectively (aa=Gly., $\mathrm{Ala}$.. and l'he.). ${ }^{21}$ Iron(II) complexes of $\mathrm{N}$-salicylidene- and $\mathrm{N}-(2-$ hydroxy-1-naphthalidene)-amino-acids (Gly. I-Ala.. /-l'he.. /-Val., /-Leul., $/$-I Iis and /-Irph have been 
previously prepared and chracaterized..$^{22}$ Nolan and Soudi $^{23}$ have prepared and characterized $\mathrm{Cu}(\mathrm{Il})$, $\mathrm{Ni}(\mathrm{II})$ and $\mathrm{Co}(\mathrm{II})$ complexes of the aspirine metabolite salicylglycine $(\mathrm{HL})$ of stoichiometry $\mathrm{M}(\mathrm{HL})_{2}{ }^{-}$ solvate, but under basic conditions, $\mathrm{Cu}(\mathrm{II})$ forms the complex $\mathrm{Cu}\left(\mathrm{LH}_{1}\right) \cdot 2 \mathrm{H}_{2} \mathrm{O} . \mathrm{MeOH}$.

The complexation of uranyl ion $\mathrm{UO}_{2}^{2}$ and pervanadyl ion $\mathrm{VO}_{2}$ with glycine have been investigated by spectrophotometric measurements in aqueous solution at $1 \mathrm{M} \mathrm{NaClO}{ }_{+}{ }^{2+}$ The spectra suggest that the coordination of the oxometal complexes is formed by the amino and carboxylate groups of glycine. Also, the preparation and reactivity of vanadium (IV) complex of $\mathrm{N}$-salicylideneglycylglycine was described and it was characterized by elemental analysis, t.g.a., d.s.c., magnetic and spectroscopic techniques. ${ }^{2.5}$

It seems to be of interest to sludy the coordination behavior of the Scliff-bases of the biologically important glycylglycine towards uranyl jon, which is quite peculiar, both in its structural and coordination chemistry. However, we report the synthesis and characterization of a series of uranyl complexes with ligands derived from the reaction of glycylglycine with salicylaldehyde; 2-hydroxy-I-naphthaldehyde; 2,3-dihydroxybenzaldelyde; and 2,4-dihydroxybenzaldehyde. These complexes are characterized by elemental analyses; conductivity measurements: magnetic susceptibility determinations: u.v., i.r. and 'II nmr spectra as well as d.t.a., 1.g. and d.s.c. techniques.

\section{EXPERIMENTAL AND METHODS}

\section{Materials}

Salicylaldehyde, 2-hydroxy-1-naphthaldehyde, 2,3dihydroxybenzaldehyde and 2,4-dihydroxybenzaldehyde were purchased from Fluka, uranyl acetate was purchased from Prolabo, and they were used as supplied. Other chemicals were reagent grade and were used without further purification.

\section{Preparation of the complexes}

All complexes were prepared according to the following procedure. To a mixture of glycylglycine $\left(10 \mathrm{mmol}\right.$ in $10 \mathrm{ml} \mathrm{H} \mathrm{H}_{2} \mathrm{O}$ ) and $\mathrm{Na}_{2} \mathrm{CO}_{3}(20 \mathrm{mmol}$ ). the aldehyde ( $10 \mathrm{mmol}$ in $10 \mathrm{ml} \mathrm{EtOH})$ is added with stirring. The mixture was heated under reflux for two hours, after which the solution acquired a yellow color indicating the formation of the Schiffbase. The following ligands were obtained:
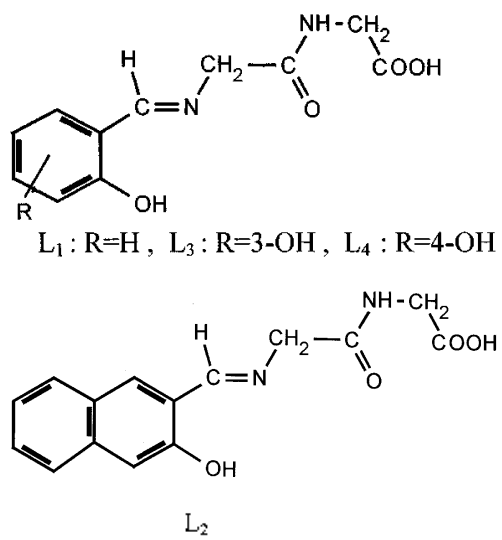

Uranyl acetate ( $10 \mathrm{mmol}$ ) was dissolved in $20 \mathrm{ml}$ $\mathrm{EtOH}$ and added to the Schiff-base ligand with stirring. Salicylaldehyde Schiff-base complex was precipitated immediately, while the complexes of the other Schiff-bases were precipitated after stirring for one hour. The complexes were filtered, washed with $\mathrm{H}, \mathrm{O}$ and $\mathrm{F}, \mathrm{OH}$ and dried under vacuum.

\section{Apparatus}

Microanalyses were performed on an Aloo CHNS932 analyzer. Uranium concentration was determined on a Fison ICP emission spectrophotometer at wavelengths $367.007,385.958$ and $409.014 \mathrm{~nm}$ using uranium standard solution. Conductivity measurements were carried out at $25^{\circ} \mathrm{C}$ on freshly prepared $10^{-3} \mathrm{M}$ DMSO solutions of the complexes using WTW conductivity meter fitted with Orion conductivity cell. I.r. spectra were recorded on Nicolet Impact 400 and Perkin-Flmer 598 spectrophotometers using nujol mull and $\mathrm{KBr}$ techniques. U.v. spectra were obtained using Beckman Du-640 spectrophotometer for freshly prepared $10^{5} \mathrm{M}$ DMSO solutions. 'Il nmr spectra were obtained with Bruker $\Lambda \mathrm{MX}-300$ in $\mathrm{DMSO}^{-} \mathrm{d}_{i 1}$ using TMS as internal standard. D.t.a., L.g. and d.s.c. were measured on a Shimadzu XD-30 thermal analyzer with heating rate $10^{\circ} \mathrm{C} / \mathrm{min}$. under atmospheric oxygen. $\mathrm{X}$-ray powder diffraction was performed using a Shi- 
Table 1. Andricual and plivisial diatia for the uranyl complexes

\begin{tabular}{|c|c|c|c|c|c|c|c|c|c|c|c|c|}
\hline \multirow{2}{*}{ Complex } & \multirow{2}{*}{ Colour } & \multirow{2}{*}{$\begin{array}{l}\text { Mol. } \\
\text { Wt. }\end{array}$} & \multicolumn{2}{|c|}{$C^{\prime \prime}{ }_{0}$} & \multicolumn{2}{|c|}{$\mathrm{H}^{0} 0$} & \multicolumn{2}{|c|}{$N^{w_{0}}$} & \multicolumn{2}{|c|}{$\mathrm{U}^{\circ}{ }_{0}$} & \multirow{2}{*}{$\begin{array}{c}\Lambda_{\mathrm{S}}^{-} \\
\text {DMSO }\end{array}$} & \multirow{2}{*}{$\bar{\lambda}_{\text {tetru }}$} \\
\hline & & & Found & Calced. & Fonnd & Calcd. & Fonnd & Caled. & found & Calcd. & & \\
\hline$\left[\mathrm{UO}_{2} \mathrm{~J}, 1\right] \mathrm{H}, \mathrm{O}$ & Orange & 521.77 & 25.1 & 25.3 & 2.4 & 2.1 & 4.2 & 4.4 & 46.1 & 45.6 & 3.96 & 276.330 \\
\hline$\left[\mathrm{UOO} \mathrm{J}_{i}\right] \mathrm{H} \mathrm{H}_{i} \mathrm{O}$ & light brown & 573.25 & 31.5 & 314 & 2.4 & 2.4 & 49 & 4.7 & 40.4 & 40.5 & 4.01 & 303.365 \\
\hline$\left[\mathrm{JO}_{2} \mathrm{~J}_{3}\right] \mathrm{H} \mathrm{H}_{2} \mathrm{O}$ & light brown & 5.38 .77 & 24.5 & 24.5 & 2.0 & 2.1 & 5.1 & 5.0 & +4.4 & 44.2 & 3.91 & 285,335 \\
\hline$\left[\mathrm{JO}_{2} \mathrm{I}, \mathrm{l}\right] \cdot 4 \mathrm{JI}_{i} \mathrm{O}$ & I,ight orange & 592.77 & $22 . .3$ & 22.3 & 2.8 & 2.7 & 4.7 & 4.7 & 42.5 & 41.9 & 2.68 & 288.340 \\
\hline
\end{tabular}

* $\Omega^{-1} \cdot \mathrm{sm}^{2} \cdot \mathrm{mol}^{-1}$

madzu XD)-3 diffractometer with ( $u-K_{\alpha}$ radiation. Magnetic susceptibilities of the complexes were measured using moditied Gour method on Johnson Mathey magnetic balanes.

\section{RESULTS AND DISCUSSION}

Results of stemental analyses are shown in Table 1 and indicate that the complexes under study have 1:1 stoichiometry: N1l complexes are dark colored solids insoluble in alcohol. acetone, pridine, diethylether. ethylene chloride and partially soluble in DMF and DMSO. The molar conductances of $10^{3} \mathrm{M}$ DMSO solutions of the uranyl complexes are too low to account for any dissociation of the complexts. All complexes ane diamagnelic as expected for an $\mathrm{JO}_{2}^{2+}$ ion.

\section{'H NMR spectra}

Room lemperalure 'H nmr spectra (DMSO-d $\mathrm{d}_{6}$ ) show three groups of signals at $\delta=6.6-7.7 \mathrm{ppm}$, live groups of signals at $\delta=7.2-8.4 \mathrm{ppm}$, wo groups of signals at $\delta=6.4-7.2 \mathrm{ppm}$ and three groups of signals at $\delta=6.1-7.5$ ppm for the aromatic protons of the uranyl complexes of $L_{1}, L_{1}, L_{3}$ and $L_{7}$ respectively: The two -Cll $\mathrm{l}_{2}$-groups of the glycylglycine moiety appear at $\delta=5.5 \mathrm{l}(\mathrm{s})$ and $\delta=5.06(\mathrm{~d}) \mathrm{ppm}$, $\delta=5.7(\mathrm{~s})$ and $\delta=5.07(\mathrm{~d}) \mathrm{pm}, \delta=5.57(\mathrm{~s})$ and $\delta=5.08(\mathrm{~d})$ ppm, $\delta=5.45$ (s) and $\delta=5.0$ (d) for the ahove mentioned complexes respectively. The characteristic signals of the aromethine group $(>C=N)$ are observed at $\delta=9.35,10.2,9.37$ and $9.25 \mathrm{ppm}$ for the complexes respectively ${ }^{20} \mathrm{On}$ the other hand, the $0-\mathrm{OH}$ protons on the pheny] and naphbyl rings did not observed. ${ }^{2 / 3}$ "This contims that bonding to the ligands takes place through displacement of the protons from the o-Oll groups on the phenyl and naphthyl rings. The $\mathrm{m}-\mathrm{OH}$ and $\mathrm{p}-\mathrm{Oll}$ protons of ligands $L_{3}$ and $L_{1}$ resonate at $\delta=8.15$ and $\delta=10 \mathrm{ppm}$ indicating that they do not take place in bonding to the uranyl ion. The $-\mathrm{NH}$ protons appeared at $\delta=10.2$, $10.43,10.36$ and $10.28 \mathrm{ppm}$ respectively. Therefore the NH groups are not involyed in bonding through complex fomation. The protons of $\mathrm{O}-\mathrm{OH}$, $\mathrm{p}-\mathrm{OH}$ and $\mathrm{NH}$ groups on the ligands are exchangeable with $\mathrm{D}_{2} \mathrm{O}$ of all compleses. The disappearance of the COOI signal in the comples spectra indicates the ionization of the carboxylic group.

\section{I.R. spectra}

The IR spectra of the complexes are quite complex (Tahle 2), however; a few assignments are helplul to the structural work. Water is detected by a broad band due to its - 0 OH centered at 3580.3556 . 3600 and $3500 \mathrm{~cm}^{-1}$ respectively. The Strong sharp ahsoption bands of the amide $\left(v_{\mathrm{NH}}\right)$ appeared at $3370.3344,3320$ and $3287 \mathrm{~cm}^{-1}$. Sharp bands al 3105. 3099,2945 and $2928 \mathrm{~cm}^{-1}$ in the spectra of the complexes may the assigned to $\mathrm{v}_{13}\left(\mathrm{CI}_{2}\right)$ (Table 2$)$.

Strong broad split bands, in the $\mathrm{C}=\mathrm{O}$ stretching region, are observed in the spectra of all complexes. They have maxima at: 1658.1639 and $1595 \mathrm{~cm}^{1}$ for $\left[\mathrm{UO}_{2} \mathrm{~L}_{1}\right] . \mathrm{I}_{2} \mathrm{O}: 1660,1640.1605$ and $1578 \mathrm{~cm}{ }^{1}$ for $\left[\mathrm{UO}_{2} \mathrm{~L}_{2}\right] . \mathrm{I} \mathrm{I}_{2} \mathrm{O}: 1653,1629.1596$ and $1556 \mathrm{~cm}^{1}$ for [UO $\left.\mathrm{O}_{2} \mathrm{I}_{3}\right] \cdot \mathrm{H}_{2} \mathrm{O}$; and 1631 ; 1599 and $1560 \mathrm{~cm}^{-1}$ for $\left[\mathrm{JO}_{2} \mathrm{I}_{1}\right]-4 \mathrm{H}_{2} \mathrm{O}$. These bands may be assigned $\mathrm{t} o$ : $v(\mathrm{CH}=\mathrm{N})$ indicative of imine structure, the-CONH group (amide $I$ hand) $)^{2-}$ and the coordinate carhoyylate group. ${ }^{25}$ The $v_{\mathrm{sym}}\left(\mathrm{COO}^{-}\right)$bands are ohserved alt $1422,14.30,1407$ and $1390 \mathrm{~cm}^{-1}$ respectively: ${ }^{20.10}$

The strongest evidence for complexation of the uranyl ion with the Schift-bases under investiga- 
Table 2. Inliared spectral bands of the uranyl complexes

\begin{tabular}{|c|c|c|c|c|}
\hline $\begin{array}{l}\text { Complex } \\
\text { Assignment }\end{array}$ & {$\left[\mathrm{JO}_{\mathrm{i}} \mathrm{I}_{\mathrm{l}}\right] . \mathrm{II}, \mathrm{O}$} & {$\left[\mathrm{UO}_{i} \mathrm{I}_{i}\right] \cdot \mathrm{H}_{i} \mathrm{O}$} & {$\left[\mathrm{IO}_{i} \mathrm{I}_{3}\right] \cdot \mathrm{H}_{i} \mathrm{O}$} & {$\left[\mathrm{JO}_{i} \mathrm{I}_{4}\right] \cdot 4 \mathrm{II}_{i} \mathrm{O}$} \\
\hline$\overline{v\left(\mathrm{IJ}_{i} \mathrm{O}\right)}$ & $.3580 \mathrm{sh}$ & $3556 \mathrm{sh}$. & $3600 \mathrm{sh}$. & $3500 \mathrm{sh}$. \\
\hline$v(\mathrm{NI})$ & $3370 \mathrm{sh}$ & $3344 \mathrm{br}$ & $3320 \mathrm{sh}$. & 3287 sh. \\
\hline$v_{0 x}\left(\mathrm{CII}_{i}\right)$ & $3105 \mathrm{sh}$. & $\begin{array}{l}3099 \mathrm{br} \\
3936 \mathrm{w}\end{array}$ & $2945 \mathrm{w}$ & 2928 s.br. \\
\hline $\begin{array}{l}v(\mathrm{CH}-\mathrm{N}) \\
v(-\mathrm{CONH}) \\
v_{\mathrm{se}}(\mathrm{COO})\end{array}$ & $\left.\begin{array}{l}1658 \\
1639 \\
1595\end{array}\right]$ s.br. & $\left.\begin{array}{l}1660 \\
1640 \\
1605 \\
1578\end{array}\right]$ s.br. & $\left.\begin{array}{l}1653 \\
1629 \\
1596 \\
1556\end{array}\right]$ s.br. & $\left.\begin{array}{l}1631 \\
159 \% \\
1560\end{array}\right]$ s.br. \\
\hline 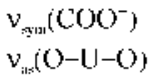 & $\begin{array}{l}1422 \mathrm{sh} . \\
914 \mathrm{ss.}\end{array}$ & $\begin{array}{l}1430 \mathrm{sh} . \\
910 \mathrm{ss}\end{array}$ & $\begin{array}{l}1.407 \mathrm{sh} . \\
918 \mathrm{ss}\end{array}$ & $\begin{array}{l}1390 \mathrm{sh} . \\
910 \mathrm{s.s.}\end{array}$ \\
\hline
\end{tabular}

tion is the apposance of characteristic stretching frequutency of dioxouranium ion $\mathrm{UO}_{2}^{2-}$ in the i.r. specta of the formed complexes. Accordingly, strong bands in the region 910-918 $\mathrm{cm}^{-1}$ (Table 2) in the spectra of the studied complexes are assigned

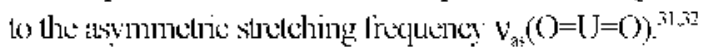

\section{U.V. spectra}

The electronic spectra of the complexes in $10^{\circ} \mathrm{M}$ DMSO solutions (Tahle l) show a number of bands in the u.v region. The absomption bands appearing at $276 \mathrm{~mm}\left(\mathrm{~L}_{1}\right), 303 \mathrm{~mm}\left(\mathrm{~L}_{2}\right), 285 \mathrm{~nm}\left(\mathrm{~L}_{3}\right)$ and 288 nm $\left(L_{.1}\right)$ may be attributed to berzenoid $\Pi \rightarrow \Pi^{*}$ transitions. Absorplion hands at $330 \mathrm{~nm}\left(\mathrm{~T}_{1}\right), 365$ $\mathrm{nm}\left(\mathrm{T}_{2}\right), 335 \mathrm{~nm}\left(\mathrm{~T}_{3}\right)$ and $340 \mathrm{~nm}\left(\mathrm{~T}_{1}\right)$ are assigned to conjugate imine $\Pi \rightarrow \Pi^{*}$ transitions of the aldimine which were observed with other Schill-hases. ${ }^{33}$

\section{Thermal studies}

The results of simultaneous d.ta.-l.g and d.se. analyses of the complexes are shown in Fig. 1 and Table 3. The abrupt weight loss observed in both t.g. and d.ta. curves at temperatures $87^{\circ} \mathrm{C}, 50-170^{\circ} \mathrm{C}$, $72-130$ ' $\mathrm{C} .50-130^{\prime \prime} \mathrm{C}$ and the corresponding endothetmic peaks are due to dehydration. ${ }^{3+}$ This is tesponsible for the color change from light brown to hrown $\left(\left[\mathrm{JO}_{2} \mathrm{I}_{2}\right\rceil \cdot \mathrm{H}_{2} \mathrm{O}\right.$ and $\left.\left\lceil\mathrm{JO}_{2} \mathrm{I}_{3}\right\rceil \cdot \mathrm{H}_{2} \mathrm{O}\right)$, and from orange to brown $\left(\left\lceil\mathrm{JO}_{2} \mathrm{I}, 1 \cdot \mathrm{H}_{2} \mathrm{O}\right.\right.$ and $\left\lceil\mathrm{JO}_{2} \mathrm{I}_{1} \mathrm{l} \cdot 4 \mathrm{H}_{2} \mathrm{O}\right)$. Sinee, the dehydration lemperature of the complexes $\left\lceil\mathrm{JO}_{2} \mathrm{I}_{3}\right\rceil . \mathrm{H}_{2} \mathrm{O}$ and $\left\lceil\mathrm{JO}_{2} \mathrm{I}_{1}\right]+4 \mathrm{H}_{2} \mathrm{O}$ is almost the same $\left(72-130^{\circ} \mathrm{C}\right)$, this may he due to both complexes have the same substiluents in benzene ring (two -OI groups). The i.r. spectra of the conplexes and their dehydrated foms show no differ-

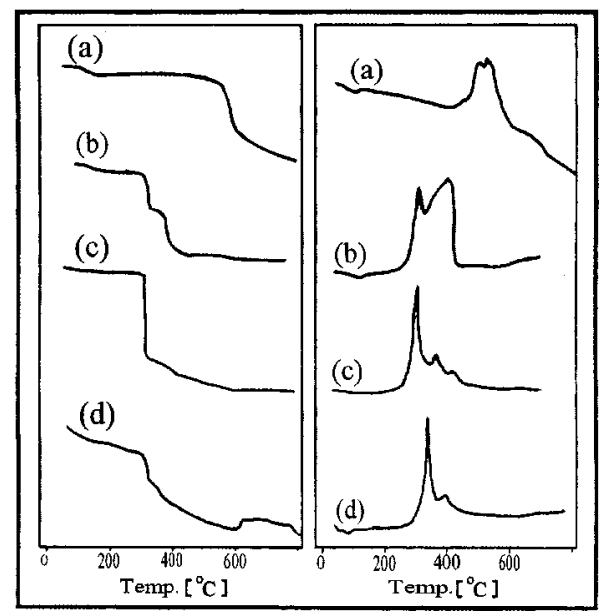

Fig. 1. D.ta and I.g.a. spectra of the complexes. (a) $\left|\mathrm{UO} \mathrm{O}_{2} \mathrm{~L}_{1}\right| \cdot \mathrm{H}_{2} \mathrm{O}$. (b) $\left|\mathrm{U} \mathrm{O}_{2} \mathrm{~L}_{2}\right| \cdot \mathrm{H}_{2} \mathrm{O}$. (c) $\left|\mathrm{U} \mathrm{O}_{2} \mathrm{~L}_{1}\right| \cdot \mathrm{H}_{2} \mathrm{O}$. (d) $\left[\mathrm{LO} \mathrm{O}_{2} \mathrm{~L}_{+} \mid \cdot 4 \mathrm{H}_{2} \mathrm{O}\right.$.

ences. This indicate that this part of hydration water makes no contribution to the lattice forces and is trapped in the crystal roids ${ }^{33.31}$

Moreover, the X-ray pattern of the compleses $\left[U \mathrm{O}_{2} \mathrm{~L}_{4}\right] . \mathrm{I}_{2} \mathrm{O}$ and $\left[\mathrm{UO} \mathrm{O}_{2} \mathrm{~L}_{+}\right] .4 \mathrm{I}_{2} \mathrm{O}$ atter dehy dration is characterized by a number of retlections compared to before dehydration (Fig. 2). This indicates that degree of erystallinity is obtained alter dehydration..$^{\text {r }}$

The exothemic peaks within the kemperalure range $340-373^{\circ} \mathrm{C}$ for $\left\lceil\mathrm{JO}_{2} \mathrm{~T}_{1}\right\rceil \mathrm{H}_{2} \mathrm{O}$ and $350^{\circ} \mathrm{C}$ for [UO, I, $]. \mathrm{H}_{2} \mathrm{O}$ are assigned to themal degradation and partial decomposition as indicated from their thermoproducts in the same temperature range. The sharp exothemic peaks in the temperature range 
Table 3. D.t.a., t.g.a. and d.s.c. peaks and their assignments

\begin{tabular}{|c|c|c|c|c|c|}
\hline Complex & $\begin{array}{l}\text { D.t.a. and d.s.c. } \\
\text { Fno. }\end{array}$ & Endo. & Assignment & $\begin{array}{c}\text { T.g. Found(Calcd. }) \\
\left({ }^{0}{ }_{0}\right)\end{array}$ & Losstype \\
\hline \multirow[t]{6}{*}[\mathrm{JO}_{i}\mathrm{I}_{1}]{. $\mathrm{H} \mathrm{H}_{i} \mathrm{O}$} & $87(\mathrm{DTA})$ & - & Dehỵdration process & $3.2(3.14)$ & $\mathrm{II}_{i} \mathrm{O}$ \\
\hline & - & $.340(\mathrm{DSC})$ & Degradation & - & - \\
\hline & - & $37.3(\mathrm{DTA})$ & Partial decomposition & - & - \\
\hline & 420 (DSC) & - & Fusion and saporization & - & - \\
\hline & - & $433(\mathrm{DSC})$ & Final degradation and decompasition & $17.46(17.89)$ & $-\therefore-N I I C I I C O O H$ \\
\hline & $490(\mathrm{D} \mid \mathrm{A})$ & - & Solid state mechanism & - & - \\
\hline \multirow[t]{5}{*}{$\left|\mathrm{UO} \mathrm{O}_{2} \mathrm{~L}_{2}\right| \cdot \mathrm{H}_{2} \mathrm{O}$} & $50-170(\mathrm{DSC})$ & - & Dehydration process & $3.14(3.13)$ & $\mathrm{H}_{2} \mathrm{O}$ \\
\hline & - & $350(\mathrm{DTA})$ & Partial decomposition & $21.48(20.8)$ & $-\therefore-\mathrm{CH}_{2} \mathrm{CONHCH}$ \\
\hline & $380(\mathrm{DSC})$ & - & Fusion and raporization & $26.4(25.7)$ & \\
\hline & - & $465(\mathrm{DTA})$ & Final decomposition & - & - \\
\hline & - & $500(\mathrm{DSC})$ & Solid state reaction & - & - \\
\hline \multirow[t]{5}{*}[\mathrm{JO}_{2}\mathrm{J}_{3}]{$\cdot 11_{2} \mathrm{O}$} & $72-130(\mathrm{DSC})$ & - & Dehỵdration & $3.3(3.5)$ & $\mathrm{II}_{2} \mathrm{O}$ \\
\hline & - & $341(\mathrm{DT} \wedge)$ & Partial decomposition & - & - \\
\hline & $395(\mathrm{DSC})$ & - & Fusion and raporization & - & Side chain and ligand \\
\hline & - & 409 (DTA) & Final decomposition & $48.19(47.49)$ & - \\
\hline & - & $473(\mathrm{DT} \wedge)$ & Solid state reaction & - & - \\
\hline \multirow[t]{6}{*}[\mathrm{UO}_{2}\mathrm{I}_{1}]{$+41 \mathrm{I}_{2} \mathrm{O}$} & $50-70(\mathrm{DSC})$ & - & Deln dration procssitakes flace in two stepls & $12.14(12.14)$ & $4 \mathrm{H}_{2} \mathrm{O}$ \\
\hline & $70-130(\mathrm{DSC})$ & & & & \\
\hline & - & $300-335(\mathrm{D} \mid \mathrm{A})$ & P'artial decomposition & $12.48(12.14)$ & $--\mathrm{NHCH}_{2} \mathrm{COOH}$ \\
\hline & $389(\mathrm{DSC})$ & - & Fusion and raporization & - & - \\
\hline & - & $348(\mathrm{DTA})$ & Oxidution degradation & - & - \\
\hline & - & 420 (DTA) & Final decomposition & - & - \\
\hline
\end{tabular}

Complexes $\left.\mid \mathrm{UO} \mathrm{O}_{2} \mathrm{~L}_{2}\right] \cdot \mathrm{H}_{2} \mathrm{O}$ and $\left|\mathrm{UO} \mathrm{O}_{2} \mathrm{~L}_{3}\right| \cdot \mathrm{H}_{2} \mathrm{O}$ hare slability zones at $600-800^{\circ} \mathrm{C}$ which are altributed o the fonmation of metal oxides.

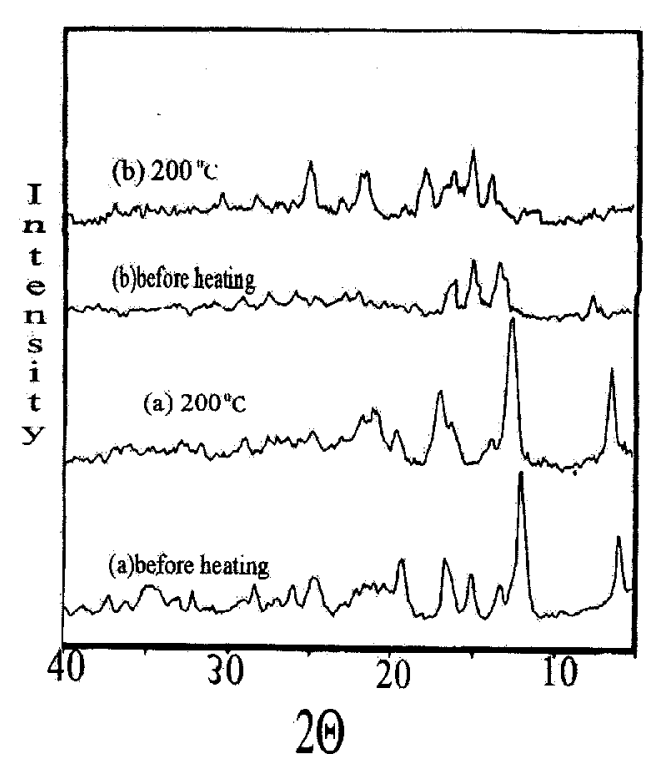

Figg. 2. X-ray diftraction patten of the complexes. [ [JO, $\left.\mathrm{I}_{2}\right] . \mathrm{H}_{2} \mathrm{O}$ (b) $\left[\mathrm{JO}_{2} \mathrm{I}_{1}\right] \cdot 4 \mathrm{II}_{2} \mathrm{O}$. $\left(380-395^{\circ} \mathrm{C}\right.$ ) for the omplenes $\left[\mathrm{TO} \mathrm{I}_{2}\right] \cdot \mathrm{H}_{2} \mathrm{O} \cdot\left[\mathrm{TO}_{2} \mathrm{I}_{3}\right] \cdot \mathrm{H}_{2} \mathrm{O}$ and $\Gamma \mathrm{NO}_{2} \mathrm{I}_{1}, 4 \mathrm{H}_{2} \mathrm{O}$ are attributed to fusion and vaporization, ${ }^{3+}$ followed by an exothemic peaks al the temperature range $\left(409-465^{\circ} \mathrm{C}\right)$ corresponding to the final decompesition. ${ }^{35}$

I.g. curves (Fig. I) indicate that decomposition of the anlydrous complexes follow immediately after dehydration process with different mechanisms. ${ }^{35}$ The partial decomposition of all complexes start at temperatures $373^{\circ} \mathrm{C}, 350^{\circ} \mathrm{C} .341^{\circ} \mathrm{C}$ and $300^{\circ} \mathrm{C}$. As demonstrated by t.g. and i.r. spectra. neither amide carbenyl at $1640 \mathrm{~cm}^{-1}$ nor $\mathrm{N}-\mathrm{H}$ in the range 3320 $3370 \mathrm{~cm}^{-1}$ are present. This implies the mechanism of decomposition of the complexes [UO $\left.\mathrm{O}_{2} \mathrm{~T}_{2}\right] \cdot \mathrm{H}_{2} \mathrm{O}$ and $\left[\mathrm{JO}_{2} \mathrm{I}_{3}\right]-4 \mathrm{H}_{2} \mathrm{O}$. which does hegin be scission of the side chain of the ligand $-1-\mathrm{CH}-\mathrm{C}-\mathrm{NH}-\mathrm{CH}_{2}-\mathrm{COOH}$.<smiles>[CH-]=C</smiles>

But for the complex $\left\lceil\mathrm{JO}_{2} \mathrm{I}_{1}\right\rceil . \mathrm{H}_{2} \mathrm{O}$, the pathway of ther 


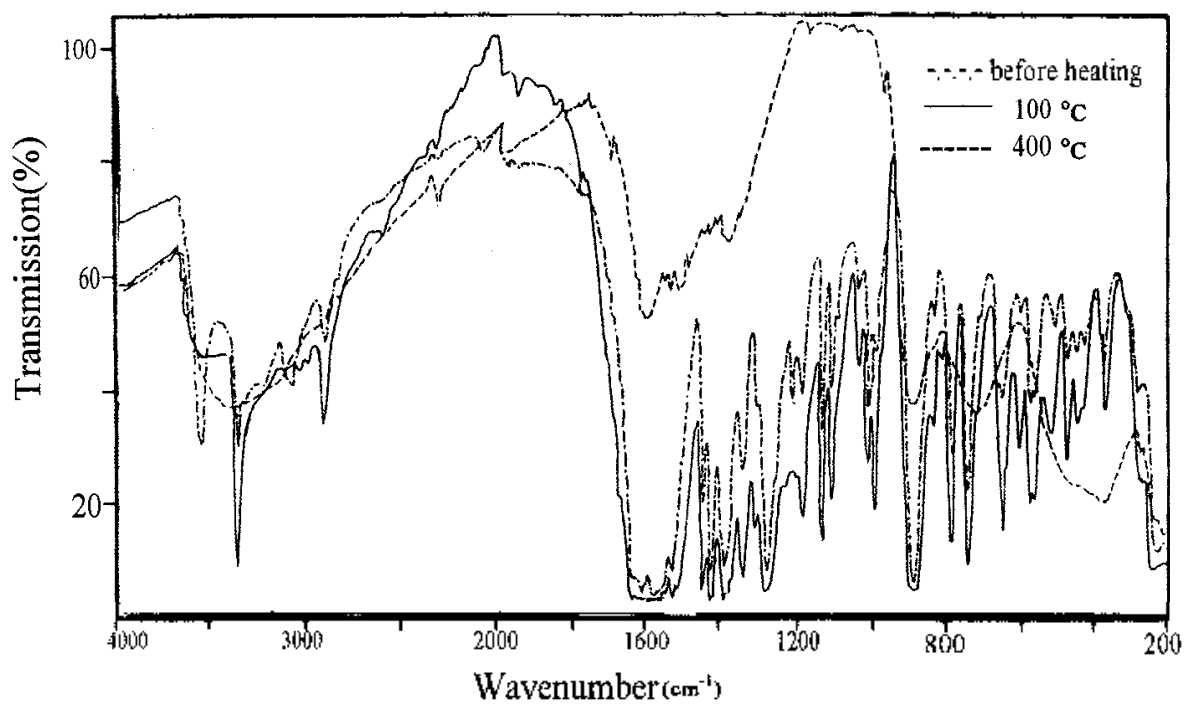

Fig. 3. Inlrared spectra of the $\left|\mathrm{UO} \mathrm{O}_{2} \mathrm{~L}_{1}\right| \mathrm{I} \mathrm{I}_{2} \mathrm{O}$ complex before and alter heating.

mal decomposition can be represented as follows: complex $\left[\mathrm{UO}_{\underline{1}} \mathrm{~L}_{1}\right] \cdot \mathrm{H}_{2} \mathrm{O}-\mathrm{I} 00^{\circ} \mathrm{C} \rightarrow$ anhydrous form and its i.r. spectrum of the anhydrous form (/. /g. 3) shows the absence of $-\mathrm{CONH}-$ at $1640 \mathrm{~cm}^{1}$. is This means that the transformation $-\mathrm{C}^{*}-\mathrm{N}: \mathrm{H} \rightarrow-\mathrm{C}_{0, \mathrm{~N}}$ takes place since $-\mathrm{C}-\mathrm{O}$ bands at 1200 and $1300 \mathrm{~cm}^{-1}$ are still present" with increasing intensity after dehydration, then decomposition start by fission of the $-\mathrm{C}-\mathrm{H}-\mathrm{N}-\mathrm{CH}_{2}-\mathrm{COOH}$. The products of thermal decomposition of the complexes are seen in lable 3 .

Based on the above analylical data and physicochemical properties, the following structure is proposed in which uranyl ion is coordinated through azomethine nitrogen, oxygen of the ionized phenolic hydroxyl group, the carbonyl and caboxylate groups of the glycine moeity.

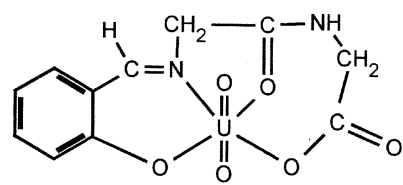

\section{REFERENCES}

1. Dubey. S. N.: Vaid. B. K. Sinth Retet. Inorg. Mtt.Org. Chem. 1991. 21. 1299.
2. Battacharya. P. K. J. Indian. Chent. Soc. 1982, 52, 505 .

3. Г!1-Hendawy, A. M.: Г:I-Kourashy, F, G.: Shanab, V. M. l'olyhedron 1992. /l. 523.

4. Mathews. I. I.: Joy. I. A.: Vasudevan. S.: Manohar. HI. Inorg. (hem. 1991. 36). 2181.

5. Pyrц. J. W.: Roe. A. I.: Stem. L. I.: QUE. Jr. L. J. Am. Chen. Soc. 1985. 107. 614.

6. Martell. A. E.: Szpoganicz. B. Inorg. Chem. 1989. 28. 4199.

7. Aminabhavi. T. M.: Birader. N. S.: Patil. S. B.: Roddabasenaggoudar. V. L.: Rudzinski. W. E. Inomg. Chem. Acta 1985. 107. 231.

8. Weller. M. G.: Weser. L: . . Am. Chem. Soc. 1982. 104. 3752 .

9. Olivard. J.: Mutzlut. D. Г..: Snell, Г. F. . B. Biol. Chem. 1952. 199. 279.

10. Holm, R, H. in Inorganic Biochemistry. Eichhorn, G, I..(ed.). F.Isovicr. Vew York. 1973, p. 1137.

II. Burrows. R. C..: Báilar. Jr. I. C.. J. horg. Nitcl Chem. 1967. 29. 709 .

12. Cassella I.: Ciulloti, M.: Pintar, A.: Messori, I.: Rockenbaucr, A.: Gyor: M. horg. Chem. 1987, 26. 1031.

13. Percy, G. C. J, horg Attcl Chem. 1975, 37, 2071.

14. Cassella. I.: Gulloti, M. Inorg. Chem, 1986. 25, 1293.

15. Theriot L. J.: Carlisle, C. O.: I Iu. II. L. J. Inorg Nitcl. Chem. 1969, 31, 2891.

16. Nakao. Y.: Sakuraj. K.: Nakahara. A. Bufl. Chem. Soc. Jpn. 1967. 40. 1536.

17. Cassella. L.: Pusini. A.: lgo. R.: Visca. M. J. Chem. Soc. Daton. Trms. 1980. 1655; Cassella. L.. Ciulouti. 


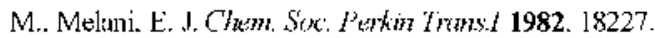

18. Cassella. L.: Gullotii. M.: P'acchioni. G. J. Am. $C / h^{\prime} m$. Soc. 1982. 104. 2386.

19. Shanthi. R.: Nagaraja. K. S.: Udupa. M. R. lnng. Chim. Act 1987. 133. 211 .

20. Cassella. J.: Gullotti, M. J. Am. (Them. Soc. 1983, 105. 803: ihid Inorg. Chem. 1983. 22. 2259

21. Sattari, O: Nlipour. F.: Shirani, S., Amighian, J. $J$. Iforg. Brochem. 1992, t5, 115.

22. Sharma. P. K.: Dubey: S. N. Intikn J. (hem 1994. 33.1, 1113.

23. Nolan, K. B.: Soudi, K. K. Forg. ( $/ \mathrm{h}^{2}$. Ltota 1995. 230. 209 .

24. J agrange, P.h.: Schneider, M.: 7are. K: I.agrange, J. Plowhedom 1994. 13.861.

25. Cavaco, I.: Pessoa, I.C:- I uz, S.M: Durate, M.T. Polyhedfon $1995,14,429$.

26. Klink. R.E.: Stothers. J.B. Cand. I. Chem. 1952. 40. 1071: Ranganathan. H.: Ramaswamy. D.: Ramasami. l': Santappa. M. Clem. Lell. 1979. 1201: Rvabokoby1ko. Yu.S.: Kurkorskava L. N.. Shapelko. N. N. Russ. J. Strater. Chem. 1974. 15. 783.

27. Silverstein. R. M.: Bassler. G. C. Spectrometric ldentification of Organic Componds. Wiley. New York. 1967. Ch. 3.

28. Nakamolo. K. Spectroscopy and Structure of Metal Chelate Compounds. Nakimoto. K. and McCarliy l'.l. (eds.). Wilev: New York. 1968. Cl. 4.
29. Tevssie. P.: Charette. J. J. Spectochm .fofa 1963. J9. 1407: Kovacic. I.E. ihid 1967, 23A. 183: Kuddick. J:: Sams. R. J. J. Organumb Cham. 1973. 6(1. 233.

30. Hodgsom. I. B.: P’ercy. G. C. Spectroxhim. Acta 1967. 32.1. 1291 .

31. Nakamoto, K. Intrared and Raman Spoetra of Inorgantic and Coordination compounds, $3^{\text {sd }}$ ed. Wiler-Interscience. New York, 1978. p.327; Okkahu. K.: Nakamoto. K. Inorg. Chem. 1970, 10,798

32. Comyns. A. F.: Gatchouse. B. M.: Wait, Г.. J. Chem. SOC. 1985, 4655 .

33. Cassella. I..: Gullotti, M. J. Im. ('hem. Soc 1981. 103 . 6.3 .38 .

34. Wendlandt. W.W. I. Ihorg. Hucl (1hem 1963. 25, 833; Donia, A.M.: Abou Г.1-F.nein. S.: Masoud. M. S. Thermochim. icta 1990. 161. 217.

35. Donia, A.M.: Avad. M.I: Issa, R.M. Transitien M/et. ( $h$ 'm. 1991. 16. 518 .

36. Donia. A.M.: Ayad. M.I. Hontash. Chem. 1993. 124. 981.

37. Ferranand. R.: House. Ir. J. E. J. Inory. Find. Chem. 1972. 34. $221 \%$ : Graber. M.: Aynd. M. M.: Ayad. M. I. Thermochim. Acta 1991. 176. 21.

38. Yamada. M.: Araki. K.: Shiraishi. S. Bull. Chom. Soc. Jpn. 1987. 60. 3149.

39. Gaber. M.: Mabrouk. H. A.: Balssa. A. A.: Avad. M. M. Honatsh. Chem. 1992. 123. 1089: Karanj. K. K.: Singli M. K. Transition Het. Chem. 1987. 12. 385. 